\title{
DRIFTING TOWARDS AMBIGUITY: A Closer LoOK AT PALATALISATION IN L2 IRISH
}

\author{
MARINA SNESAREVA
}

Despite the fact that the modern Celtic languages have received a great deal of scholarly attention, a number of phonetic phenomena observed in Irish are yet to be fully explained. Most studies in this field concern speakers of traditional Irish dialects rather than new speakers of Irish, and are descriptive. ${ }^{1}$ This article focuses on palatalisation in the Irish spoken by Dublin-based bilinguals for whom English is their first language. All informants had a good knowledge of both Irish and English; however, Irish was their second language, used less frequently in everyday communication. Most Dubliners start learning Irish at school; only a few informants had the opportunity to speak it at home, but even then the language was not used outside class on a regular basis.

\section{The language situation in Ireland}

Nowadays Irish is, on the one hand, the first official language of Ireland, while on the other, English is the first language of most Irish people, and for many of these it is their only language. Even those living in the Gaeltacht areas are fluent in English and can easily switch to it when the use of Irish is impossible or unwelcome. Knowledge of Irish is specified in national censuses but throughout the twentieth century censuses have not reflected actual language-use, being based on speakers' opinions alone.

The 2011 census was the first to include more detailed data, reporting that of the 1.7 million who claimed knowledge of Irish, only 55,500 used it in everyday communication outside the classroom. When pupils speaking Irish both at school and outside class are also taken into account, it emerges that 94,000 use Irish on a daily basis [Central Statistics Office]: this corresponds to $5.3 \%$ of all declared Irish speakers or $2.15 \%$ of the country's population (see Image 1 ):

\footnotetext{
${ }^{1}$ In sociolinguistics the language of younger generations of Irish speakers is often called 'post-traditional' or 'non-traditional' Irish (Ó Béarra 2007), and the speakers themselves are referred to as 'semi-speakers' (Dorian 1981; Lenoach 2012; Ó Curnáin 2012). They differ from older generations of speakers due to insufficient language competence and noticeable deviations in grammar and pronunciation. The term 'new speakers' was introduced to move away from the negative connotations of the previous labels as well as to emphasise the importance of such speakers in language maintenance and revitalisation.
} 


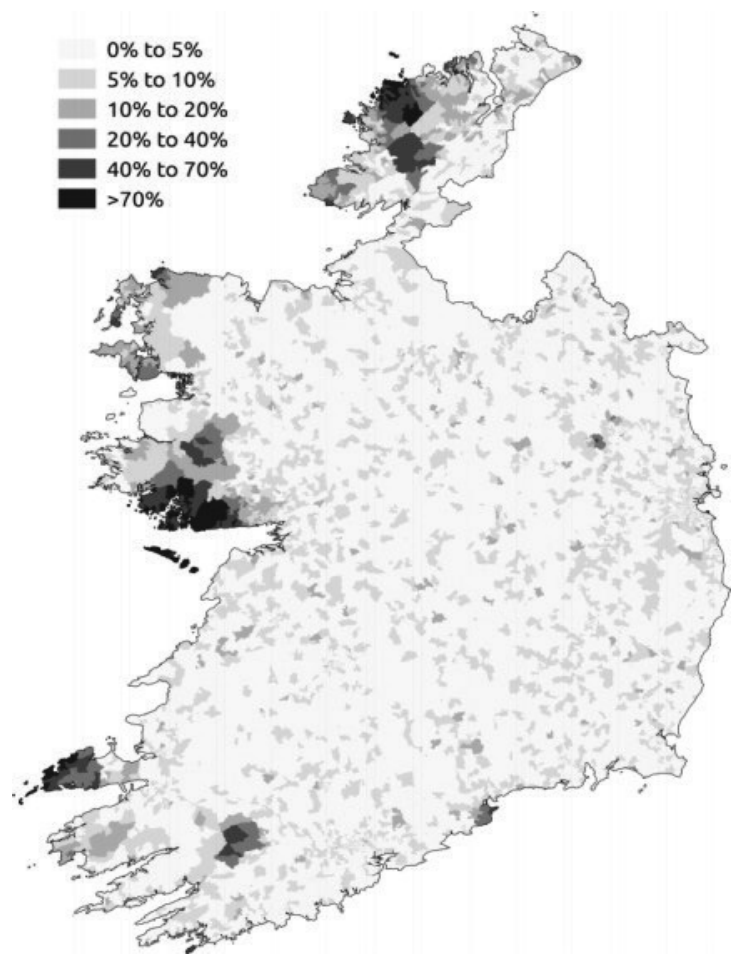

Image 1. Daily speakers of Irish according to the 2011 census [Central Statistics Office]

The attitudes towards Irish in contemporary Irish society are varied. Older speakers may have a negative attitude towards the language due to their school experience, as up until the 1970s it was necessary to pass a language test to obtain a higher-learning certificate (Carnie 1996: 109), while the attitudes of younger speakers are heavily influenced by their occupation and political views, by their family's attitude towards the language, and by whether (and how often) Irish is used with parents and siblings (O'Rourke 2005: 287-288).

Nowadays, Irish has a predominantly symbolic value which gives the population of Ireland a sense of cultural unity. The majority of young speakers have a positive attitude towards the language, and its symbolic value is not questioned (Moffatt 2011: 149-151), even though for most instances of communication Irish has long been replaced by English. However, the necessity of the Irish language for Irish identity is no longer obvious: after all, in everyday life, the Irish are more likely to choose English over Irish than the other way round (Ó Riagáin 2007; Moffatt 2011). 
The attitude of the Irish towards English is also ambiguous: while the majority of the country's population have English as their first language, they are reluctant to admit this (Hickey 2009). As a result, even though there have been a number of studies of Irish English (e.g. Ó Muirithe 1977; Kallen 1997; Kirk \& Ó Baoill 2001; Amador-Moreno 2010; Hickey 2011), there is a dearth of sociolinguistic data on the use of, and attitudes towards, the English language in Irish society. Most surveys conducted both on the official level (census) and for scientific purposes provide only data concerning Irish.

\section{Study background}

One distinctive feature of the Irish consonant system is the opposition of palatalised and non-palatalised consonants. In Irish, palatalisation is systemic and performs phonological functions (Hickey 2014). Thus, for Irish class 1 nouns such as bád 'boat', palatalisation of the final consonant is used to form the genitive singular and nominative plural. Depalatalisation can also be used to form the genitive singular (cf. máthair 'mother-NOM.SG', máthar 'mother-GEN.SG'), though this happens less frequently. In English, on the other hand, palatalisation is strictly allophonic and can only occur before the high front vowel [i:].

The data used in the study include speech samples recorded in Dublin in November 2014 when thirty-six Dublin bilinguals - 20 male and 16 female - with English as their first and Irish as their second language were interviewed. All informants were born and raised in Dublin, had no immediate Gaeltacht connection, and at the moment of interview lived either in the city or in neighbouring counties. They belonged to different age groups, yet most respondents ( 24 informants, or $67 \%$ ) were no older than 35 (see Image 2):

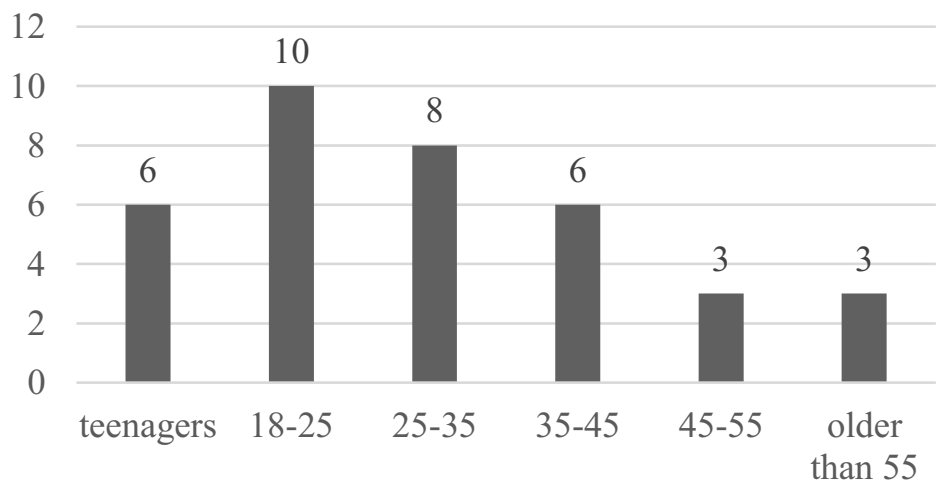

Image 2. Dublin informants: age groups and number of speakers 
For the study to be valid, Irish consonants had to be pronounced in different positions. The main part of the interview consisted of words and wordcombinations the informants were asked to read aloud; 53 word-combinations were recorded in Irish and 31 in English. This allowed me to record Irish and English consonants in various positions as well as to minimise the potential influence of other factors on the speakers' pronunciation, such as the incorrect use of noun cases. Word-final palatalisation presence or absence in the recorded data due to the use of a nominative form in the context that requires genitive etc., had thus to be excluded. At the same time, read speech is often hypercorrect, and in spontaneous conversation, deviations and mispronunciations are likely to be more frequent.

Computer speech analysis was performed in each context to ensure that palatalisation or its absence was defined with the highest degree of certainty. Acoustic analysis was conducted using freely available software (Boersma \& Weenink 2015) and followed by calculation of the number of deviations and their frequency. When determining whether a consonant is palatalised or not, the surrounding vowels must also be considered, in order to take account of accommodation (Knyazev \& Pozharitskaya 2012: 104-105): the formant frequencies of neighbouring vowels are measured both in the stationary phase (the middle segment where no noticeable changes of formants are observed) and in the transition phase (the segment immediately following or preceding the consonant), in order to record their changes.

Thus, when a low back or mid-back vowel is pronounced next to a palatalised consonant, the second formant F2 of the vowel rises in the transition phase (i.e. immediately after the consonant or before it), which can be observed on the spectrogram (see Image 3):

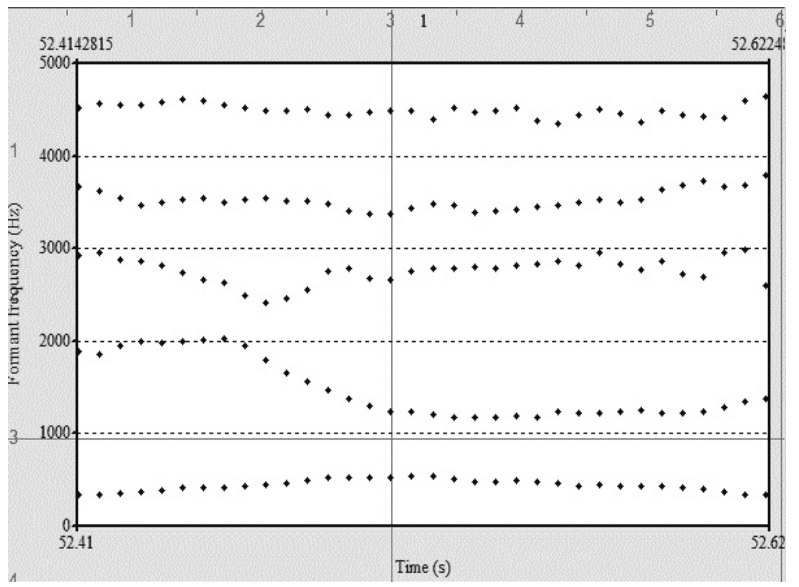

Image 3. Vowel formants change after a palatalised [b'] in beag 'small' 
When a front vowel occurs next to a palatalised consonant, its F2 remains unchanged. Next to non-palatalised consonants the situation is different: here the second formant F2 of low back and mid-back vowels does not change and remains quite low (see Image 4), while F2 of front vowels appears to be somewhat lower in the transition phase:

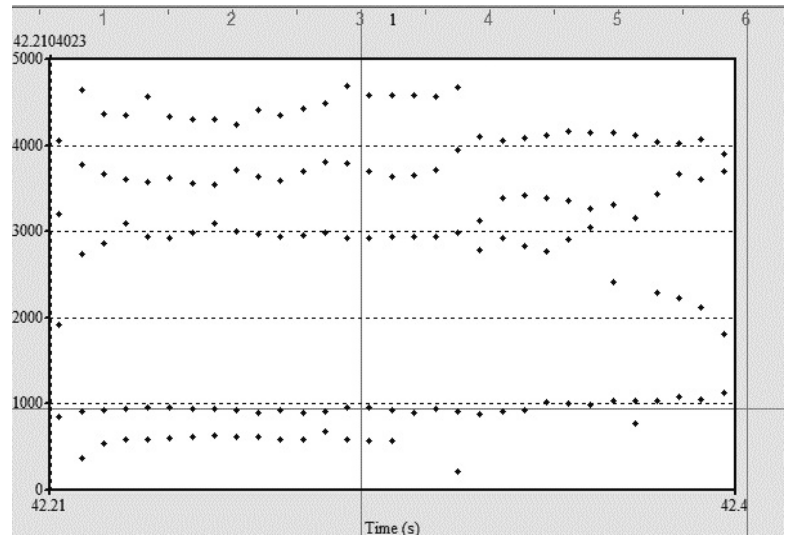

Image 4. Vowel formants change after a non-palatalised [b] in bocht 'poor'

\section{Palatalisation in Dublin English}

Despite the fact that the opposition of palatalised and non-palatalised consonants is absent in English, instances of allophonic palatalisation were observed in the informants' data. Their speech was characterised by a number of features, including specific articulation of velar stops $[\mathrm{k}]$ and $[\mathrm{g}]$ : in some cases, and especially word-finally, these consonants could acquire additional palatalisation.

In the recordings, word-final $[\mathrm{k}]$ occurred in the nouns book and desk, and [g] in bag. In these contexts, [k] was palatalised by seven informants, while over half of the respondents pronounced a palatalised [g'] in bag. For example, word-final [k] in desk was palatalised by informant 32. In this case the first formant F1 of the preceding vowel remained unchanged, the frequency of the second formant F2 was invariably high ([e] is a front vowel), and the frequency of the third formant F3 increased in the transition phase (see Image 5): 


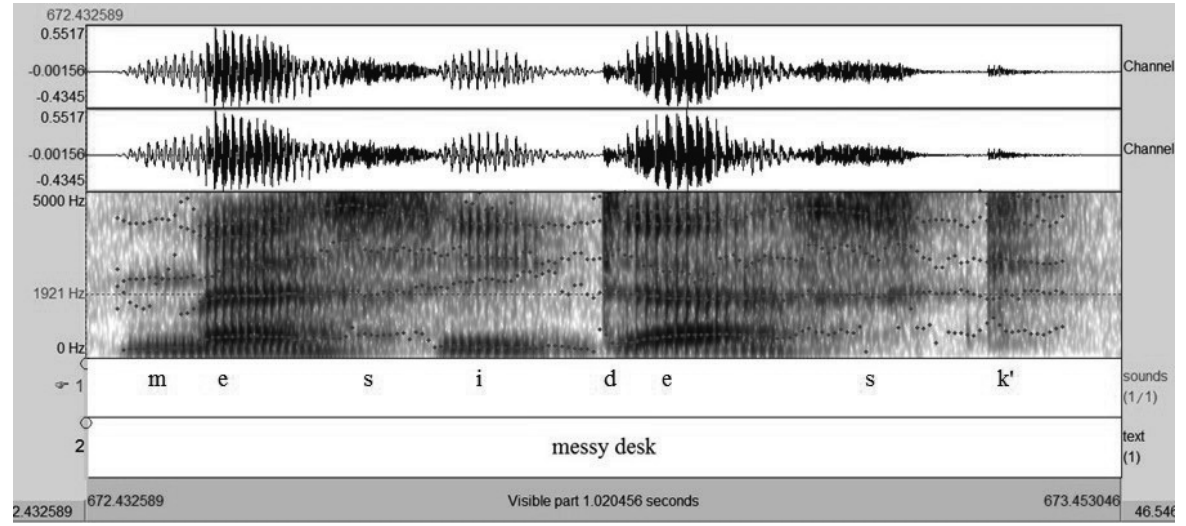

Image 5. Messy desk: a palatalised [k'] in desk (informant 32)

When a front vowel is pronounced next to a non-palatalised consonant, the frequency of its F2 usually becomes lower in the transition phase; in the above example, however, the lowering does not happen, which may indicate palatalisation.

In messy desk [k] becomes palatalised after a front vowel; i.e., palatalisation in this context may be position-bound. After all, allophonic palatalisation has already been observed in English before high front vowels (Guenther 1995; Bateman 2007; Pavlík 2009). ${ }^{2}$ In my data, allophonic palatalisation could occur in the following words: ticket, village, piece, feeble, beads, geese and needle, and indeed, some speakers - albeit not all of them palatalised initial consonants in these contexts. For instance, informant 36 pronounced a palatalised [p'] in piece (see Image 6):

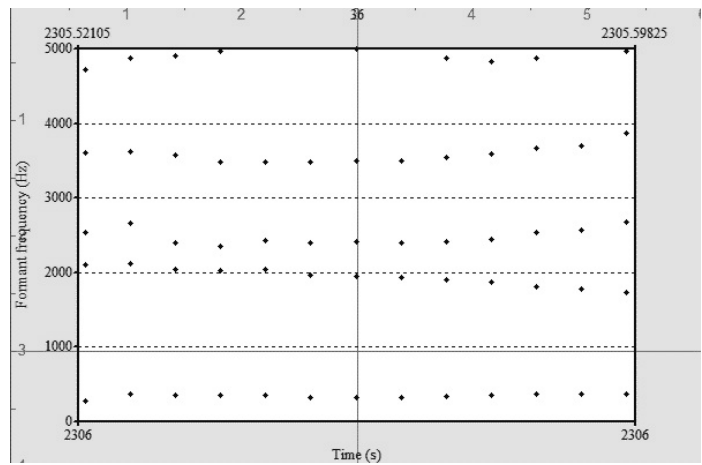

Image 6. Vowel formants change when [p] is palatalised (informant 36)

\footnotetext{
${ }^{2}$ Not all researchers call this phenomenon palatalisation. N. Bateman (2007: 41-42), for example, defines secondary articulation of velar stops before [i] as velar fronting and believes that this phenomenon differs from palatalisation proper, while R. Pavlík (2009: 15) defines secondary articulation of stops next to high front vowels as palatal assimilation.
} 
In this example, F1 and F3 of the vowel remain unchanged, while F2 appears to be somewhat higher in the transition phase after the consonant, reaching $2100 \mathrm{~Hz}$. The fact that the frequency of F2 remains high in the transition phase may signify palatalisation of the preceding consonant. Indeed, when a non-palatalised [p] is pronounced in the same context, F2 and F3 of the following vowel are slightly lower immediately following the consonant, as opposed to their frequencies in the stationary phase (Image 7):

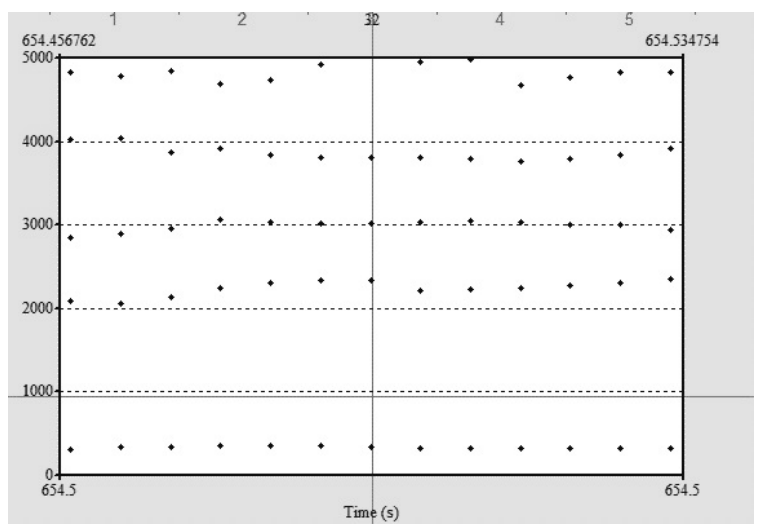

Image 7. Vowel formants change when [p] is not palatalised (informant 32)

In the transition phase after the consonant, formant frequencies of the vowel are as follows: F1 - 280-320 Hz, F2 - 2055-2090 Hz, F3 - 2840$2920 \mathrm{~Hz}$, whereas in the stationary phase they are thus: F1 $-310-335 \mathrm{~Hz}$, F2 - 2235-2345 Hz, F3 - 3010-3030 Hz. When comparing Images 6 and 7 , it becomes evident that vowel formants behave differently in the transition phase: while in the first case F2 and F3 rise by $100-200 \mathrm{~Hz}$, in the second example they fall by $200-300 \mathrm{~Hz}$.

All in all, the pronunciation of the Dublin informants was rather uniform: several instances of palatalisation before the high front vowel [i:] were found in their speech, thus confirming that allophonic palatalisation could occur in Dublin English.

\section{Palatalisation in Dublin Irish}

Turning to Irish, only strong positions were analysed in the study, since deviations here are more significant. For Irish palatalised and nonpalatalised consonants, such positions are the following: word-initially before a stressed vowel, intervocalically after a stressed vowel and wordfinally after a long or stressed vowel; / $r$ / is the only exception, the first position for this sound being substituted by the second element of a wordinitial consonant cluster. 
The number of deviations in palatalisation varied, but the average percentage for fluent Irish bilinguals was quite low: 733 instances of mispronunciation were singled out in total, corresponding to $11.9 \%$ of analysed consonants. This means that a competent Dublin bilingual ${ }^{3}$ with Irish as his/her second language pronounces $88 \%$ of consonants as expected. In spontaneous speech, however, deviations are likely to be more frequent.

Palatalisation absence accounted for the majority of deviations (646 instances out of 733 , or $88.13 \%$ of all deviations) and was observed in all strong positions. Word-initially, palatalisation was absent in 182 examples out of 1044: i.e., in $17.43 \%$ cases. Most deviations in this position concerned liquids, nasals and the voiceless labial fricative [ $\left.\mathrm{f}^{\mathrm{f}}\right]$; these usually occurred before back vowels or, in a smaller number of cases, before [e:]. For example, 30 informants out of 36 pronounced [f] instead of [f'] in fear 'man', as is visible on the spectrogram (Image 8):

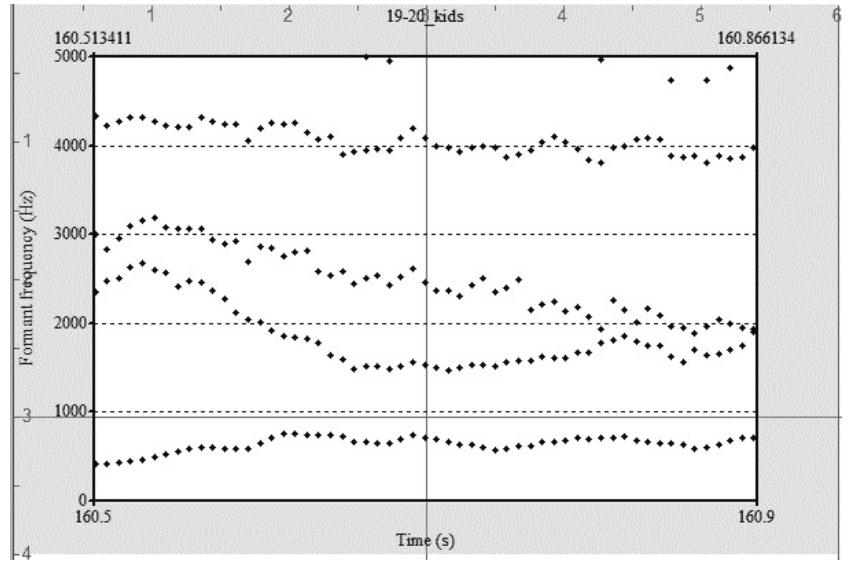

Image 8. Vowel formants change after a palatalised [ $\mathrm{f}]$ in fear 'man' (informant 19)

When analysing the formants of the following long vowel [a:], a lowering of F1 and a noticeable rise of F2 from $1400-1500 \mathrm{~Hz}$ to $2200-2600 \mathrm{~Hz}$ are observed in the transition phase; the rise of F2 in this case signifies that the preceding consonant is palatalised.

\footnotetext{
${ }^{3}$ By a competent speaker I mean a bilingual who has a good knowledge of both English as his/her first language and Irish as his/her second language, and is capable of using the latter in oral and written communication without switching to English. If informants could not actively participate in conversation and give detailed answers in Irish, their data were deemed unsuitable for analysis. The questions used in the interview did not concern any specialised subjects and do not reflect the speakers' ability to use Irish in professional communication.
} 
When the initial consonant in fear 'man' is not palatalised, the formants of the following vowel behave in a different way. In this case, the frequencies of F1 and F2 remain unchanged, and F2 does not exceed 1200 $\mathrm{Hz}$ (the analysed vowel is a back vowel), as can be seen Image 9:

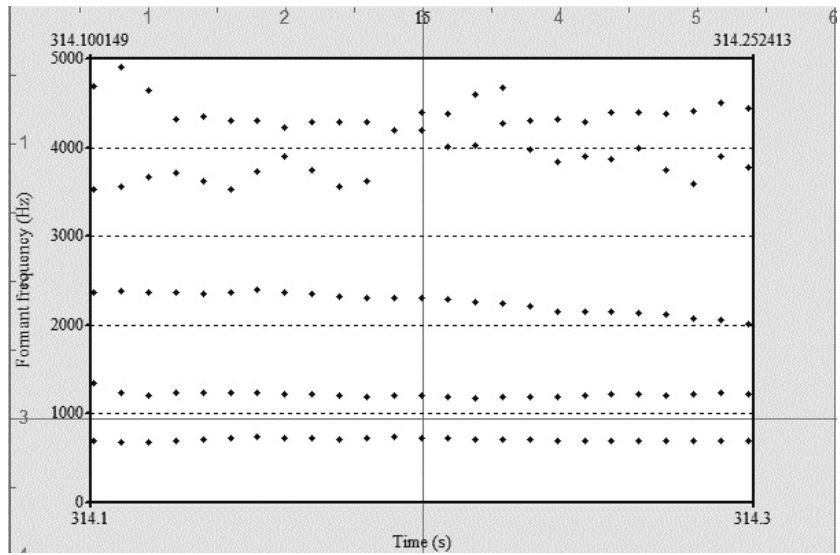

Image 9. Vowel formants change after a non-palatalised [f] in fear 'man' (informant 15)

Intervocalically, palatalisation was absent in 146 examples out of 720: i.e., in $20.28 \%$ of the cases. In this position, deviations concerned not only liquids and nasals but also labial stops and labial fricatives, especially [p'], [f'] and [v']. Most deviations occurred after the back and mid-back vowels [a], [a:], [o] and [o:]; however, in the case of sonorants, palatalisation was also absent after [i:] (for example, in tíre 'country-GEN.SG' and dílis 'dear'). ${ }^{4}$

Although palatalization absence was observed in all positions, the majority of such deviations were encountered word-finally (318 instances out of 720 , or $44.17 \%$ of cases). Here, palatalisation was often absent in the case

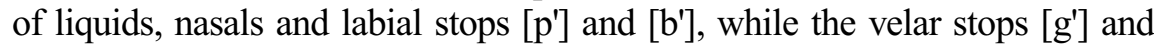
$\left[\mathrm{k}^{\prime}\right]$ showed the fewest deviations. ${ }^{5}$ In this position there seem to be a correlation between palatalisation absence and the neighbouring vowel length, as quite a number of deviations occurred after long vowels, irrespective of their frontness or backness. Besides, deviations were often found after back and mid-back vowels.

A palatalised consonant was produced instead of a non-palatalised one in 87 cases, accounting for $11.87 \%$ of all deviations. Even though

\footnotetext{
${ }^{4}$ Some notes on the use of palatalised and non-palatalised sonorants in L2 Irish can also be found in Snesareva 2014a; 2015.

${ }^{5}$ It should be pointed out that the corresponding sounds were often palatalised in the informants' English data as well.
} 
I expected the majority of them to be of the palatalisation absence type, deviations of the second type were also observed in the data. As opposed to palatalisation absence, such deviations mostly occurred word-initially.

A comparatively low number of such deviations can indicate instability of palatalisation in the speech of L2 Irish bilinguals as a result of English influence. Thus, word-initially, a palatalised consonant was pronounced instead of a non-palatalised one in 63 examples out of 1872: i.e., in only $3.37 \%$ of cases. Most deviations in this position concerned the alveolar stops [t] and [d] (18 and 35 examples respectively).

Intervocalically, deviations were observed in 16 instances out of 864: i.e., $1.85 \%$ of cases. This happened in only one context: in Ir. bádóir 'boatman' a palatalised consonant [d'] was produced by several informants. As was the case word-initially, most mispronunciations concerned alveolar [d] (13 instances).

As opposed to palatalisation absence, the number of deviations found word-finally was extremely low ( 8 instances, or $0.85 \%$ of all analysed consonants in this position). Most deviations in this position were observed for alveolar [d] and [r]. Thus, irrespective of consonant position in the word, the majority of second type deviations concerned the voiced and voiceless alveolar stops [t] and [d]. As a rule, palatalisation occurred before front vowels, but this does not exclude contexts like tús [tu:s] 'beginning' and buachaill [buəxəl'] 'boy', as the speakers who used $\left[\mathrm{t}^{\prime}\right]$ and $\left[\mathrm{b}^{\prime}\right]$ in these words pronounced a fronted vowel rather than a back one, also as the first element of the diphthong [uə] (Image 10):

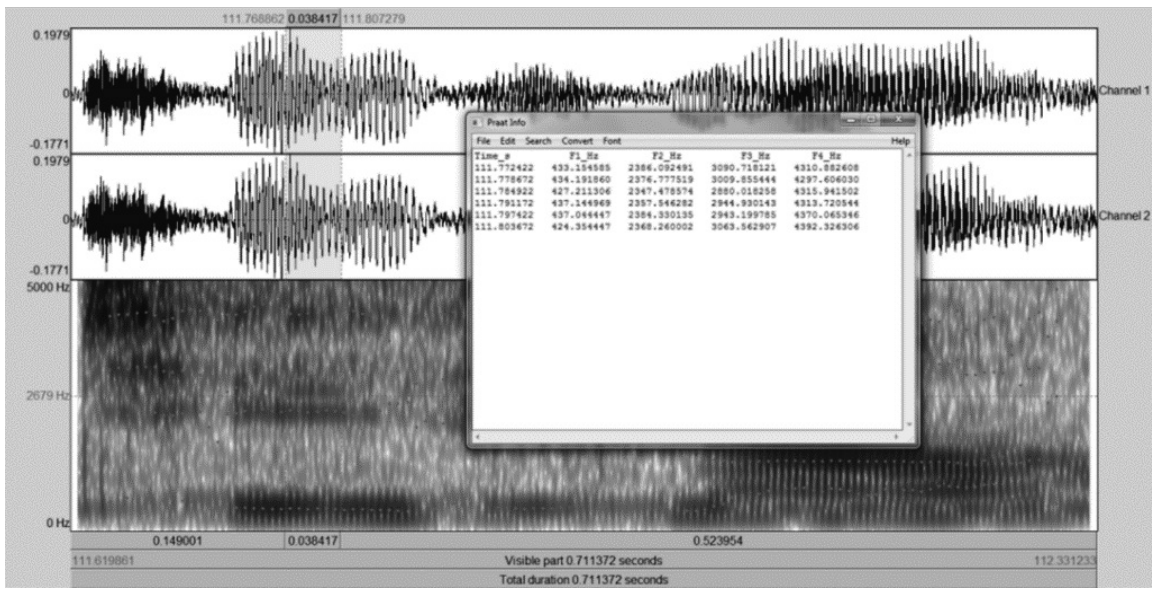

Image 10. [t'] and a fronted vowel in tús 'start', formants measured in the stationary phase 


\section{Grounds for ambiguity}

In the speech of Dublin bilinguals, palatalisation was often absent wordfinally, even when it resulted in noun number and case ambiguity. Thus, 13 informants pronounced a non-palatalised $[t]$ instead of a palatalised [ $\left.\mathrm{t}^{\prime}\right]$ in cait 'cat-GEN.SG', whereas in this case palatalisation is used to form the genitive singular and nominative plural of the noun, cat [kat] meaning 'cat-NOM.SG' and 'cat-GEN.PL', and cait [kat'] being 'cat-GEN.SG' and 'cat-NOM.PL'.

Ambiguity could also result from deviations of the second type: for example, three informants pronounced [d'] instead of [d] in bád 'boat' (see Image 11), where palatalisation or absence thereof is also used to differentiate between word forms, with bád [ba:d] meaning 'boat-NOM.SG' or 'boat-GEN.PL' and báid [ba:d'] signifying 'boat-GEN.SG' and 'boatNOM.PL':

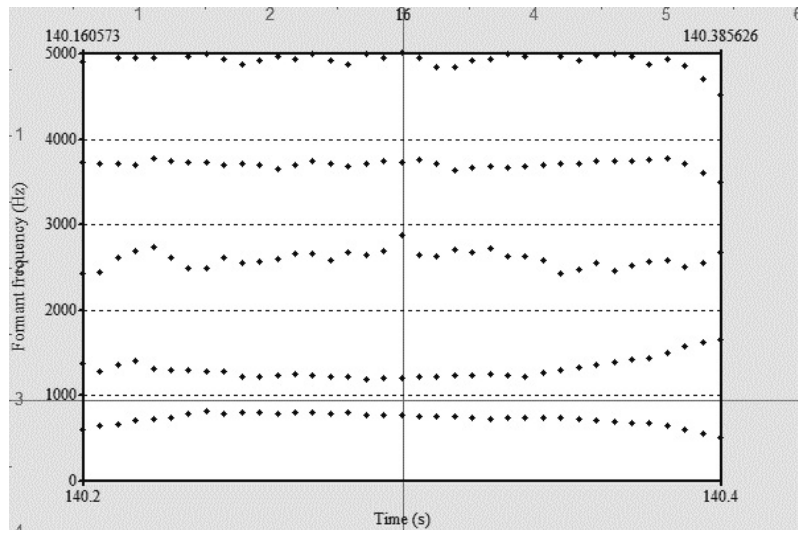

Image 11. Vowel formants change before a palatalised [d'] in bád 'boat' (informant 16)

The same phenomenon is observed in case of word-final [n']: thus, out of three available contexts (léinn 'learning-GEN.SG', cupáin 'cup-GEN.SG', ribin 'ribbon'), deviations were only found in cupáin 'cup-GEN.SG', where more than half of the informants pronounced a non-palatalised [n]. As in the previous examples, palatalisation here is used to differentiate between word forms, with cupán [n] indicating 'cup-NOM.SG' and 'cup-GEN.PL', and cupáin [ $\mathrm{n}$ '] meaning 'cup-GEN.SG' and 'cup-NOM.PL'. However, if in the case of cupán 'cup' the differentiation of word forms in speech is based solely on the palatalisation of the final consonant, in the case of cat 'cat', some speakers not only palatalised the final consonant to form the genitive singular but also pronounced a front vowel instead of a back one (cf. Image 12): 


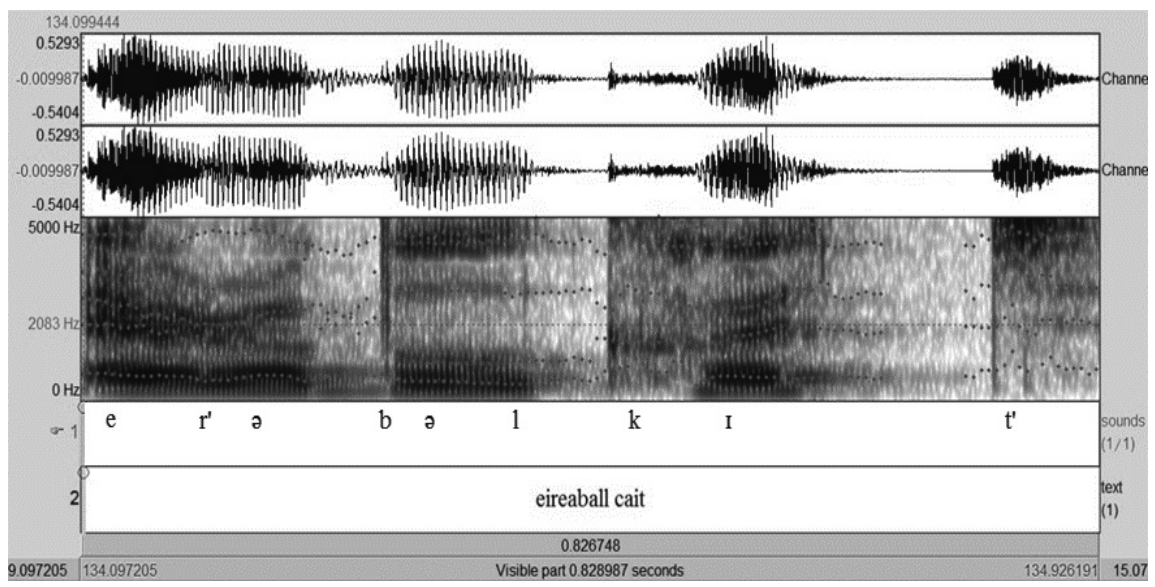

Image 12. A front vowel before [t'] in cait 'cat-GEN.SG' (informant 31)

When cait 'cat-GEN.SG' is pronounced this way, differentiation between the word forms cat [kat] and cait [kit'] is based not only on palatalisation of the final consonant but also on the quality of the preceding vowel. Consequently, in such cases, palatalisation is no longer necessary to distinguish between different forms, and deviations in its use do not result in ambiguity. This might explain why the potential convergence of word forms did not affect the speakers' verbal behaviour. However, such pronunciation is currently only a tendency: it was not characteristic of all informants and did not occur in other contexts.

\section{Conclusion}

The study showed that most deviations in the distribution of palatalised and non-palatalised consonants in the speech of Dublin bilinguals were of the palatalisation absence type. Such deviations were especially frequent next to back and mid-back vowels. On the other hand, a palatalised consonant was often pronounced instead of a non-palatalised one next to a front vowel. Previous research suggests that these tendencies also apply in weak positions (Snesareva 2014a; 2014b).

Consequently, even though in traditional Irish dialects palatalisation is not position-bound, in the speech of Dublin bilinguals there is correlation between the palatalisation of a consonant and the quality of its neighbouring vowel. However, such consonant distribution was not encountered in all contexts: even those informants whose speech had deviations used palatalisation properly in some contexts. This means that position-bound use of palatalisation is still a tendency rather than an entrenched feature of Dublin Irish. 
The data confirm that palatalisation is becoming position-bound in the speech of informants due to phonetic interference from Dublin English, where palatalisation occurs only before front vowels and is strictly allophonic. Bilingual speakers find it difficult to observe phonological oppositions in Irish, which explains why palatalised consonants are regularly pronounced next to front vowels, while in a different vowel context palatalisation is often absent. A certain parallel between the informants' languages was also found in case of the velar stops $[\mathrm{g}]$ and $[\mathrm{k}]$ : these consonants were frequently palatalised in the English data, and in the Irish material palatalised $\left[\mathrm{g}^{\prime}\right]$ and $\left[\mathrm{k}^{\prime}\right]$ had the lowest number of deviations.

Palatalisation absence or presence in the Irish speech of informants was also affected by the consonant's place of articulation and the position of the organs of speech that either facilitated or impeded palatalisation. In particular, the speakers tended to palatalise the alveolar stops [d] and $[\mathrm{t}]$ in all contexts, which was manifested in a low number of first type deviations (palatalisation absence) and a high number of second type deviations (the use of a palatalised consonant instead of a non-palatalised) for these consonants. At the same time, instances of palatalisation absence were discovered for all analysed consonants, confirming the instability of palatalisation in the speech of bilinguals. Such deviations were especially frequent in the case of bilabial and labiodental consonants, as well as with sonorants.

Finally, although in the case of Irish class 1 nouns (bád 'boat', cupán 'cup' etc.) used without the definite article, inconsistent distribution of palatalised and non-palatalised word-final consonants can result in ambiguity, it does not seem to affect the speakers' verbal behaviour.

Lomonosov Moscow State University

\section{References}

Amador-Moreno, C. P., 2010, An Introduction to Irish English, London. Bateman, N., 2007, 'A Crosslinguistic Investigation of Palatalization': unpublished $\mathrm{PhD}$ dissertation, University of California, San Diego.

Boersma, P., Weenink, D., 2015, Praat: Doing Phonetics by Computer [Computer program], Version 5.4.08, retrieved 29 May 2015 from http://www.praat.org/.

Carnie, A., 1996, 'Modern Irish. A Case Study in Language Revival Failure', MIT Working Papers in Linguistics 28, 99-114. 
Central Statistics Office [Electronic resource], (http://www.cso.ie/en/census/census2011reports/census2011profile9what weknow-educationskillsandtheirishlanguage). [Accessed 29.05.2016].

Dorian, N., 1981, Language Death. The Life Cycle of a Scottish Gaelic Dialect, Philadelphia.

Guenther, F. H., 1995, 'Speech Sound Acquisition, Coarticulation, and Rate Effects in a Neural Network Model of Speech Production', Psychological Review 102.3, 594-621.

Hickey, R., 2009, 'Language Use and Attitudes in Ireland. A Preliminary Evaluation of Survey Results', in: Ó Catháin, B., ed., Sochtheangeolaíocht na Gaeilge [Sociolinguistics of Irish]. Léachtai Cholm Cille 39, 62-89.

Hickey, R., 2011, 'Present and Future Horizons for Irish English', in: Hickey, R., ed., Irish English in Today's World. English Today: Special Issue 106, 3-16.

Hickey, R., 2014, The Sound Structure of Modern Irish, Berlin.

Kallen, J. L., 1997, Focus on Ireland, Amsterdam.

Kirk, J. M., Ó Baoill, D., 2001, Language Links. The Languages of Scotland and Ireland. Belfast Studies in Language, Culture and Politics 2, Belfast.

Knyazev, S., Pozharitskaya, S., 2012, Современный русский язык. Фонетика, орфоэпия, графика, орфография [Modern Russian. Phonetics, orthoepy, script, spelling], Moscow ( $2^{\text {nd }}$ ed.).

Lenoach, C., 2012, 'An Ghaeilge Iarthraidisiúnta agus a Dioscúrsa' [Posttraditional Irish and its Discourse], in: Lenoach, C., Ó Giollagáin, C., Ó Curnáin, B., eds., An Chonair Chaoch. An Mionteangachas sa Dátheangachas [The Blind Path. Language Minoritarity during Bilingualism], Galway, 19-109.

Moffatt, J., 2011, 'Paradigms of Irishness for Young People in Dublin': unpublished doctoral dissertation, NUI Maynooth, Maynooth.

Ó Béarra, F., 2007, 'Late Modern Irish and the Dynamics of Language Change', in: Tristram, H., ed., The Celtic Languages in Contact, Potsdam, 260-9.

Ó Curnáin, B., 2012, 'An Ghaeilge Iarthraidisiúnta agus an Phragmataic Chódmheasctha Thiar agus Theas' [Post-traditional Irish and the Pragmatics of Code-mixing in the West and in the South], in: Lenoach, C., Ó Giollagáin, C., Ó Curnáin, B., eds., An Chonair Chaoch. An Mionteangachas sa Dátheangachas [The Blind Path. Language Minoritarity during Bilingualism], Galway, 284-364.

Ó Muirithe, D., 1977, The English Language in Ireland, Cork.

Ó Riagáin, P., 2007, 'Relationships between Attitudes to Irish, Social Class, Religion and National Identity in the Republic of Ireland and 
Northern Ireland', International Journal of Bilingual Education and Bilingualism 10.4, 369-93.

O'Rourke, B., 2005, 'Attitudes towards Minority Languages. An Investigation of Young People's Attitudes towards Irish and Galician': unpublished $\mathrm{PhD}$ dissertation, DCU, Dublin.

Pavlík, R., 2009, 'A Typology of Assimilations', SKASE Journal of Theoretical Linguistics 6.1, 2-26.

Snesareva, M., 2014a, 'Дистрибуция палатализованных сонорных в выученном ирландском' [Distribution of palatalised sonorants in learned Irish], Филологические науки: вопросы теории и практики 10.3 [Philological sciences: issues of theory and practice 10.3], 170-3.

Snesareva, M., 2014b, 'Дублинцы и их ирландский: палатализация в условиях двуязычия' [Dubliners and their Irish: palatalisation in a bilingual setting], Вестник Московского университета. Серия 9, Филология 6 [Journal of Moscow State University. Series 9, Philology 6], 196-206.

Snesareva, M., 2015, 'Дистрибуция палатализованных сонорных в ирландском в речи билингвов' [Distribution of palatalised sonorants in Irish in the speech of bilinguals], in: Актуальные проблемь филологической науки: взгляд нового поколения 6 [Current issues in philology: view of the new generation 6], Moscow, 68-72. 